\title{
Photoelectrochemical solar cells using electrodeposited GaAs and AISb semiconductor films
}

\author{
S CHANDRA, N KHARE and H M UPADHYAYA \\ Department of Physics, Banaras Hindu University, Varanasi 221 005, India
}

\begin{abstract}
Electrodeposited GaAs and AlSb thin film semiconductors were prepared under various deposition conditions. Reasonable stoichiometry could be attained as revealed by EDAX studies. The best stoichiometry was obtained are $\mathrm{Ga}_{1 \cdot 04} \mathrm{As}_{0.96}$ and $\mathrm{Al}_{1 \cdot 12} \mathrm{Sb}_{0.88}$. The band gap of the GaAs and AISb films was $-1.5 \mathrm{eV}$ and $1.6 \mathrm{eV}$ respectively. The electrochemical and photoelectrochemical studies on these films are reported with different redox-couples in aqueous and non-aqueous medium.
\end{abstract}

Keywords. Photoelectrochemical cells; electrodeposition of thin films; semiconductors; GaAs films; AlSb films.

\section{Introduction}

Photoelectrochemical solar cells (PESC) are semiconductor/electrolyte junction solar cells (Gerischer 1979; Chandra and Pandey 1982; Chandra 1985). In recent years considerable progress has been made in the state-of-art of PESC and some high efficiency PESC have been successfully prepared using single crystals (Heller 1977; Parkinson et al 1979; Heller et al 1981; Tufts et al 1987; Gabouze and Gorochov 1986; Switzer 1986: Azaiez et al 1986). As single crystalline solar cells are expensive, the use of wide area semiconductor thin-film is a desirable alternative for cost reduction. The optimum band gap for PESC is $\sim 1.50 \mathrm{eV}$. We report PESC characteristics which use two promising materials viz GaAs $\left(E_{g} \sim 1.5 \mathrm{eV}\right)$ and AlSb $\left(E_{g} \sim 1.62 \mathrm{eV}\right)$. Both these materials were obtained by the electrodeposition technique described below.

For GaAs PESC, we have used three types of redox-electrolytes: (a) aqueous $\mathrm{S}^{2-} / \mathrm{S}_{2}^{2-}$ redox-couple (b) ferrocene/ferrocenium redox-couple in $\mathrm{CH}_{3} \mathrm{CN}$ and (c) $\mathrm{MV}^{2+1+}$ (methyl viologen) couple in $\mathrm{CH}_{3} \mathrm{CN}$. However, AlSb was found to hydrolyse faster in aqueous medium. Therefore, non-aqueous electrolyte $\left(\mathrm{CH}_{3} \mathrm{CN}\right.$, acetonitrile) with $2 I^{-} / I_{2}$ and nitrobenzene, $\left[\mathrm{Ph}\left(\mathrm{NO}_{2}\right)\right]^{0 /-}$ redox-couples were used for preparing PESC.

\section{Electrodeposition of GaAs}

For preparing GaAs-semiconductor films, Ga-metal and $\mathrm{As}_{2} \mathrm{O}_{3}$ were separately dissolved in concentrated $\mathrm{HCl}$. Dilute aqueous solutions were prepared later by adding the two solutions in the appropriate ratio. Ultrasonically cleaned Tisubstrate in trichloroethylene was used for electrodeposition. When electrolysis was carried out in the electrolysis cell, ionic species of $\mathrm{Ga}$ and As start moving towards cathode (Ti-substrate) and $\mathrm{Ga} /$ As gets deposited in different stoichiometric ratios depending on the deposition condition.

The electrochemical reactions for the deposition of $\mathrm{Ga}$ and As and their corres- 
ponding Nernst equations are:

$$
\begin{aligned}
& \mathrm{Ga}^{3+}+3 e^{-} \rightarrow \mathrm{Ga}(s), \\
& E_{\mathrm{Ga}}=E_{\mathrm{Ga}}^{0}+\frac{\mathrm{RT}}{3 F} \ln \left(a_{\mathrm{Ga}^{3+}} / a_{\mathrm{Ga}}\right)=-0.529+0.0197 \log \left(a_{\mathrm{Ga}^{3+}} / a_{\mathrm{Ga}}\right), \\
& \mathrm{H}_{3} \mathrm{AsO}_{3}+3 \mathrm{H}^{+}+3 e^{-} \rightarrow \mathrm{As}+3 \mathrm{H}_{2} \mathrm{O}, \\
& E_{\mathrm{As}}=E_{\mathrm{As}}^{0}+(R T / 3 F) \ln \left(a_{\mathrm{H}_{3} \mathrm{AsO}_{3}} / a_{\mathrm{As}}\right)+(R T / F) \ln a_{\mathrm{H}^{+}} \\
& \quad=0.248+0.0197 \log \left(a_{\mathrm{H}_{3} \mathrm{AsO}_{3}} / a_{\mathrm{As}}\right)-0.0591 \mathrm{pH},
\end{aligned}
$$

where the electrode potential $E^{0}$ is with respect to the normal hydrogen electrode, $a_{\mathrm{Ga}^{3+}}, a_{\mathrm{AsH}_{3} \mathrm{O}_{3}}$ are the activities of $\mathrm{Ga}$ ion and $\mathrm{H}_{3} \mathrm{AsO}_{3}$ in the solutions, $a_{\mathrm{Ga}}$ and $a_{\mathrm{As}}$ are the activities of the respective atoms in the electrodeposits, which for pure metallic deposition are equal to one. It should be noted that the activity is $\mathrm{pH}$ dependent.

For simultaneous deposition of $\mathrm{Ga}$ and As, the concentration of the solutes, the $\mathrm{pH}$ of the solution, the temperature of the electrolyte and the electrolysis current density should be adjusted such that the electrode potential of all individual deposits come closer to each other.

There are no clear-cut methods available for fixing the deposition parameters for compound film deposition. Most of the earlier attempts failed because of this. We have, in principle, used the following two procedures for fixing the starting conditions of our trial to electrodeposit GaAs.

\section{(i) Pourbaix diagram approach}

These diagrams define thermodynamical immunity regions and are represented as the plot between the electrode potential and the $\mathrm{pH}$. The Pourbaix diagrams of Ga and As are overlapped to find the common immunity region for $\mathrm{Ga}$ and As. Within this region of $\mathrm{pH}$ and electrode potential, one may expect simultaneous deposition of the two giving $\mathrm{Ga}_{x} \mathrm{As}_{y}$. Chandra and Khare (1987) used this method and found that the $\mathrm{pH}$ range 0.3 to 4.2 at about -0.8 volt (NHE) is the common immunity region.

\section{(ii) Polarization curve approach}

The $I-V$ curve is drawn at different $\mathrm{pH}$. The sudden increase in current at some electrode potential indicates the onset of deposition of one species. Similarly for other species, the current increases at another electrode potential. In between, a plateau is observed in the $I-V$ curve which indicates the region of likely simultaneous deposition of both. In this paper, we have used both these approaches.

With the initial optimization of $\mathrm{pH}=0.7$ of the electrolysis solution by the Pourbaix diagram approach, we proceeded to plot the polarization curves of GaAsfilm deposition by keeping the other deposition parameters as: $\mathrm{pH}=0.7$, temperature $=22^{\circ} \mathrm{C}$, electrolyte contained $50 \mathrm{mg}$ each of $\mathrm{Ga}$ and $\mathrm{As}_{2} \mathrm{O}_{3}$ dissolved in $\mathrm{HCl}$ to which a few drops of $\mathrm{NH}_{4} \mathrm{OH}$ were added to make the $\mathrm{pH} \simeq 0 \cdot 7$.

The polarization plot is shown in figure 1. Curves A and B were taken at different sensitivities of current axis in the X-Y recorder. Curve A (low sensitivity plot) shows 
one step only without a well-defined plateau. However, when the experiment was done at higher sensitivity (curve B), we could locate another step at electrode potential $\simeq 0.3 \mathrm{~V}$ (SCE) which corresponds to Ga deposition, while the other step at $0.7 \mathrm{~V}$ (SCE) is for As deposition. The plateau is between these two electrode potentials $(0.3-0.7 \mathrm{~V})$. We tried our electrodeposition by fixing the electrode potential in this range.

\subsection{Characterization of electrodeposited GaAs film}

\section{(a) Structural}

The stoichiometry of various films obtained at different deposition conditions was studied by the EDAX (energy-dispersive analysis by X-rays) technique. EDAX (PW 9100) attached to an electron microscope (Phillips EM-400) was used for this study. Films were electrodeposited on Ti-foils $\left(0.3 \times 0.3 \mathrm{~cm}^{2}\right)$ and were directly mounted on the stub of the EDAX sample-holder using graphite paint as a conductor between the film and the stub. The stoichiometry of the best film was $\mathrm{Ga}_{1.04} \mathrm{As}_{0.96}$. This film was obtained in 8 minutes on titanium substrate at an electrolysis current density of $2.5 \mathrm{~mA} / \mathrm{cm}^{2}$. The stoichiometry of the films obtained under different electrolysis conditions is given in figure 2 . The optimized conditions for the best films obtained are listed in table 1.

Electron diffraction patterns were also recorded using an electron microscope (Phillips TEM 200) to check the crystallinity of the film. The electrodeposited films on the substrate were scraped and the material was lifted on copper grid dipped in formvar. The observed and standard $d$-values of GaAs film (stoichiometry $\left.\mathrm{Ga}_{1.04} \mathrm{As}_{0.96}\right)$ are listed in table 2 which shows a reasonable agreement.

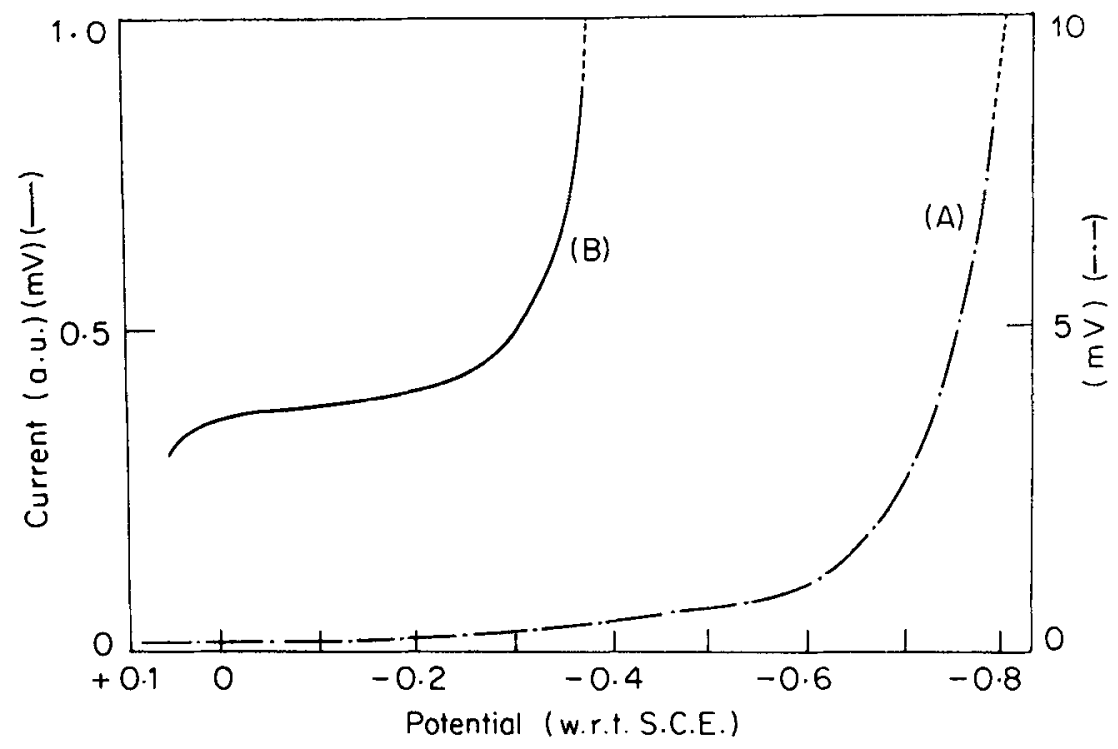

Figure 1. Polarization curve for GaAs electrodeposition. 

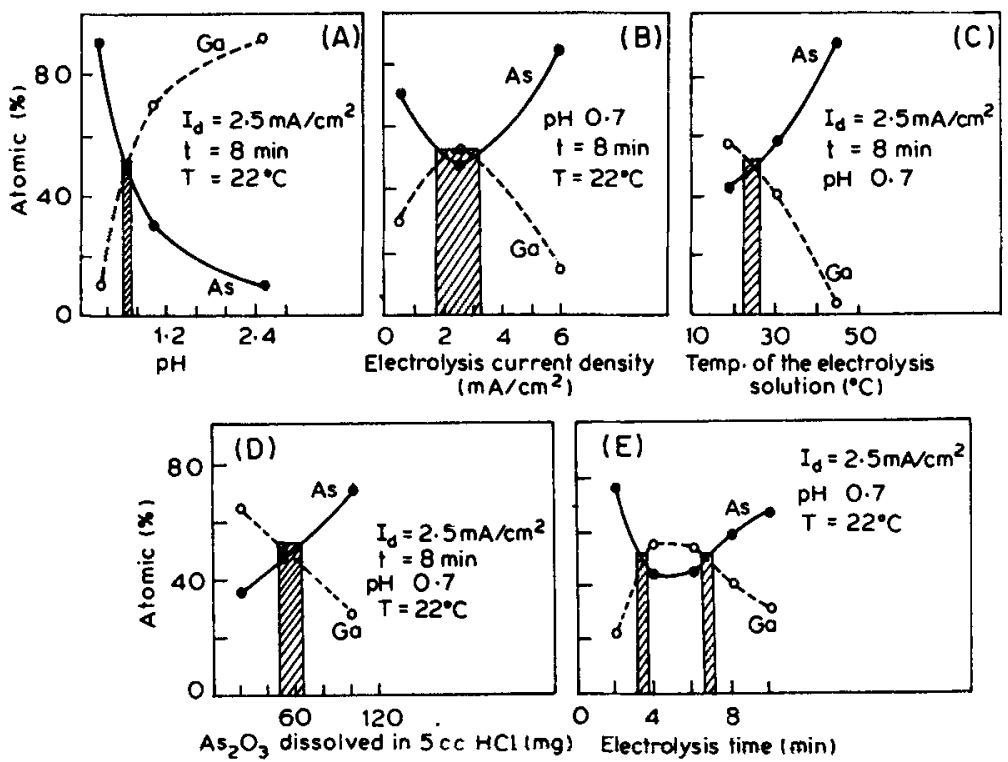

Figure 2. Relative composition of $\mathrm{Ga}$ and $\mathrm{As}$ in the electrodeposited films prepared at different (a) $\mathrm{pH}$, (b) deposition current density $I_{d}$, (c) temperature, (d) concentrations of $\mathrm{As}_{2} \mathrm{O}_{3}$ and (e) deposition time. For other conditions see table 1. In all cases except (d), $\mathrm{As}_{2} \mathrm{O}_{3}$ was taken as $50 \mathrm{mg}$ in $50 \mathrm{ml}$ of $\mathrm{HCl}$ mixed into another solution of $50 \mathrm{mg}$ of $\mathrm{Ga}$ in $5 \mathrm{ml}$ of $\mathrm{HCl}$. Shaded zones mark the region in which stoichiometry is approximately that of GaAs.

Table 1. Deposition conditions for obtaining various films. The best stoichiometry of the film obtained is noted in the column while the stoichiometry of other films can be seen in figures quoted in the same column.

\begin{tabular}{llccccc}
\hline $\begin{array}{l}\text { Stoichiometry } \\
\text { of best films }\end{array}$ & $\mathrm{pH}$ & $\begin{array}{c}\mathrm{As}_{2} \mathrm{O}_{3} \\
(\mathrm{mg} \mathrm{in} \\
5 \mathrm{ml})\end{array}$ & $\begin{array}{c}\mathrm{Ga} \\
(\mathrm{mg} \\
\mathrm{in} \\
5 \mathrm{ml})\end{array}$ & $\begin{array}{c}\text { Depo- } \\
\text { sition } \\
\text { time } \\
(\mathrm{min})\end{array}$ & $\begin{array}{c}\text { Depo- } \\
\text { sition } \\
\text { current } \\
\left(\mathrm{mA} / \mathrm{cm}^{2}\right)\end{array}$ & $\begin{array}{c}\text { Depo- } \\
\text { sition } \\
\text { temperature } \\
\left({ }^{\circ} \mathrm{C}\right)\end{array}$ \\
\hline $\begin{array}{c}\mathrm{Ga}_{1.04} \mathrm{As}_{0.96} \\
(\text { figure 2a) }\end{array}$ & $0.3-2 \cdot 5^{*}$ & 50 & 50 & 7 & 2.5 & 22 \\
$\begin{array}{c}\mathrm{Ga}_{1.06} \mathrm{As}_{0.94} \\
(\text { figure 2b) }\end{array}$ & 0.7 & 50 & 50 & 7 & $0.5-6.0^{*}$ & 22 \\
$\begin{array}{c}\mathrm{Ga}_{1.04} \mathrm{As}_{0.96} \\
(\text { figure 2c) }\end{array}$ & 0.7 & 50 & 50 & 7 & 2.5 & $22-45^{*}$ \\
$\begin{array}{c}\mathrm{Ga}_{1.06} \mathrm{As}_{0.94} \\
(\text { figure 2d) }\end{array}$ & 0.7 & $20-100^{*}$ & 50 & 7 & 2.5 & 22 \\
$\begin{array}{c}\mathrm{Ga}_{1.04} \mathrm{As}_{0.96} \\
\text { (figure 2e) }\end{array}$ & 0.7 & 50 & 50 & $2-10^{*}$ & 2.5 & 22 \\
\hline
\end{tabular}

*This parameter is varied within the range given while the others were kept fixed.

\section{(b) Band gap}

Optical absorption was studied to determine the band gap of the electrodeposited $\mathrm{GaAs}$ film. The absorption spectra were recorded at room temperature $\left(25^{\circ} \mathrm{C}\right)$ with a spectrophotometer (Hitachi-320) in transmission mode. The electrodeposited film 
was prepared on a titanium-coated semitransparent glass plate. This was used as the sample and a similar titanium coated glass plate was used as the reference.

The absorption coefficient near the absorption edge can be written as

$$
\alpha=K\left(E-E_{g}\right)^{n} / E
$$

where $K$ is a constant, $E$ the photon energy, $E_{g}$ the band gap and $n$ a constant which can be assigned values $1 / 2,3 / 2$ and 2 for allowed direct transition, forbidden direct transition and allowed indirect transition respectively. GaAs is a direct band gap material and so $n=1 / 2$.

Figure 3 shows a plot between $(\alpha h v)^{2}$ vs $h v$ which is a straight line. This confirms the direct band gap nature of the material. The intercept of the straight line with the $x$-axis gives the value of the band gap, $E_{g}=1.5 \mathrm{eV}$.

Table 2. Standard $d$-values of GaAs and those obtained from electron diffraction pattern of $\mathrm{Ga}_{1 \cdot 04} \mathrm{As}_{0.96}$ electrodeposited film.

\begin{tabular}{ccc}
\hline$h k l$ & $\begin{array}{c}\text { Standard } \\
d \text { values (A) }\end{array}$ & $\begin{array}{c}\text { Observed } \\
d \text { values (A) }\end{array}$ \\
\hline 111 & 3.26 & 3.28 \\
200 & 2.83 & 2.80 \\
220 & 1.99 & 1.94 \\
311 & 1.70 & 1.69 \\
400 & 1.41 & 1.42 \\
331 & 1.29 & - \\
422 & 1.15 & 1.16 \\
333 & 1.08 & 1.08 \\
440 & 0.99 & - \\
531 & 0.95 & - \\
620 & 0.89 & -- \\
533 & 0.86 & 0.87 \\
444 & 0.81 & - \\
711 & 0.79 & 0.78 \\
\hline
\end{tabular}

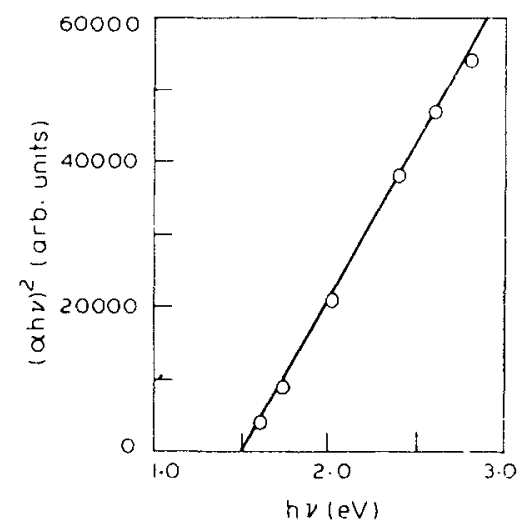

Figure 3. $h v$ vs $(\alpha h v)^{2}$ plot from the absorption spectral studies for determining the band gap of $\mathrm{Ga}_{1 \cdot(6)} \mathrm{As}_{0.94}$ film. 


\section{(c) Mott-Schottky studies}

The Mott-Schottky study is the measurement of interface capacitance with applied bias. In this study, the electrodeposited GaAs film was one electrode, the graphite was used as the counterelectrode and a saturated calomel electrode (SCE) was the third electrode. SCE was kept near the GaAs film. The electrolyte had the redoxcouple $\mathrm{S}^{2-} / \mathrm{S}_{2}^{2-}$ consisting of $1 \mathrm{M}-\mathrm{NaOH}, 1 \mathrm{M}-\mathrm{Na}_{2} \mathrm{~S}$ and $1 \mathrm{M}-\mathrm{S}$. The interface capacitance at different bias was measured by a Hewlett Packard LCR bridge model 4274A. The Mott-Schottky plot, as a representation of the variation of space charge capacitance $C_{s c}$ with the applied bias $V$ is expressed as

$$
1 / C_{\mathrm{sc}}^{2}=\left(2 / \varepsilon_{s} \varepsilon_{0} q N_{D}\right)\left[V-V_{\mathrm{fb}}-(k T / e)\right],
$$

where $V_{\mathrm{fb}}$ is the flat band potential, $\varepsilon_{s}$ the dielectric constant of the semiconductors, $\varepsilon_{0}$ the permittivity of free space, $q$ the electronic charge and $N_{D}$ the doping density. The intercept on $X$-axis gives the flat band potential, $V_{\mathrm{fb}}$. Further, from the slope of the straight line the value of $N_{D}$ can be calculated.

Figure 4 shows the Mott-Schottky plot of the electrodeposited $\mathrm{Ga}_{1.04} \mathrm{As}_{0.96}$ film dipped in $\mathrm{S}^{2-} / \mathrm{S}_{2}^{2-}$ electrolyte. The nature of the plot indicates that the film is $n$-type. The values of $V_{f b}$ and $N_{D}$ were obtained as $-1.4 \mathrm{~V}$ (SCE) and $8.7 \times 10^{15} \mathrm{~cm}^{-3}$ respectively.

\section{Electrodeposition of AlSb}

$\mathrm{Al}_{2}\left(\mathrm{SO}_{4}\right)_{3}$ and $\mathrm{Sb}_{2} \mathrm{O}_{3}$ were the starting material for the preparation of electrodeposited $\mathrm{AlSb}$ thin film. The compounds were dissolved in conc. $\mathrm{HCl}$ solution, then a well-polished Ti-substrate was rinsed and cleaned in trichloroethylene by putting it in an ultrasonic cleaner tank. When the titanium substrate is dipped in the electrolyte containing $\mathrm{Al}_{2}\left(\mathrm{SO}_{4}\right)_{3}$ and $\mathrm{Sb}_{2} \mathrm{O}_{3}$, deposition reaction of $\mathrm{Al}$ and $\mathrm{Sb}$ takes place as given below:

$$
\begin{aligned}
& \mathrm{Al}^{3+}+3 e \rightarrow \mathrm{Al}(s) \\
& E_{\mathrm{Al}}=E_{\mathrm{Al}}^{0}+(R T / 3 F) \ln \left(a_{\mathrm{Al}^{3+}} / a_{\mathrm{Al}}\right)=-1.662+0.0197 \log \left(a_{\mathrm{Al}^{3+}} / a_{\mathrm{Al}}\right) \\
& \mathrm{HSbO}_{2}+3 \mathrm{H}^{+}+3 e^{-} \rightarrow \mathrm{Sb}(s)+3 \mathrm{H}_{2} \mathrm{O} \\
& E_{\mathrm{Sb}}=E_{\mathrm{Sb}^{0}}+(R T / 3 F) \ln \left(a_{\mathrm{HSbO}_{2}} / a_{\mathrm{Sb}}\right)+(R T / F) \ln a_{\mathrm{H}^{+}} \\
& \quad=0.23+0.0197 \log \left(a_{\mathrm{HSbO}_{2}} / a_{\mathrm{Sb}}\right)-0.0591 \mathrm{pH}
\end{aligned}
$$

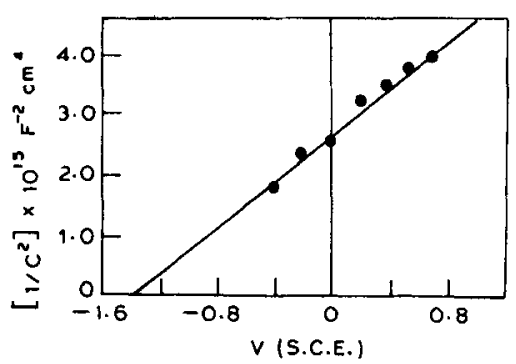

Figure 4. Mott-Schottky plot for electrodeposited GaAs film. 
Antimony is a more noble metal than aluminium and its deposition tendency is greater than $\mathrm{Al}$. Also, $\mathrm{Al}$ being a greater non-reducible metal, the deposition of $\mathrm{Al}$ at room temperature and low current electrolysis is difficult. Thus, for a balance of situation, we have taken the concentration of $\mathrm{Al}_{2}\left(\mathrm{SO}_{4}\right)_{3}$ much higher than the conc. of $\mathrm{Sb}_{2} \mathrm{O}_{3}$, typically in the ratio of $1000: 1$. The above approach of fixing deposition parameters does not permit deduction of enough guidelines to fix the electrode potential and the electrolysis current density. For this, we use the polarization curve as for GaAs. A typical $I-V$ curve is given in figure 5 . The $\mathrm{pH}$ of the solution plays an important role for the AlSb system. AlSb, by nature, is chemically highly corroding in the aqueous medium. The $\mathrm{pH}$ range of 3.0 to 4.0 gives a good quality of deposition.

The stoichiometry of AlSb films prepared under different conditions is given in figure 6. All depositions were done at electrolysis current density $=2 \mathrm{~mA} / \mathrm{cm}^{2}$ at $32^{\circ} \mathrm{C}$. The best film had the stoichiometry $\mathrm{Al}_{1 \cdot 12} \mathrm{Sb}_{0 \cdot 88}$.

\section{Results on PESC's and discussion}

The photoelectrochemical solar cells of GaAs and AlSb were fabricated by depositing these films on the Ti-electrode as one electrode and platinum plate as the counterelectrode dipped in a suitable redox-electrolyte.

The PESC of GaAs were studied both under the aqueous and non-aqueous redoxcouples. The aqueous $\mathrm{GaAs} / \mathrm{S}_{2}^{2-}, \mathrm{S}^{2-}$ system yielded a typical open circuit voltage, $V_{\mathrm{oc}}$, of $195 \mathrm{mV}$ and a short circuit current $J_{\mathrm{sc}}$ of $2.2 \mathrm{~mA} / \mathrm{cm}^{2}$ for $60 \mathrm{~mW} / \mathrm{cm}^{2}$ illumination intensity for the film of stoichiometry $\mathrm{Ga}_{1.04} \mathrm{As}_{0.96}$. It was found that

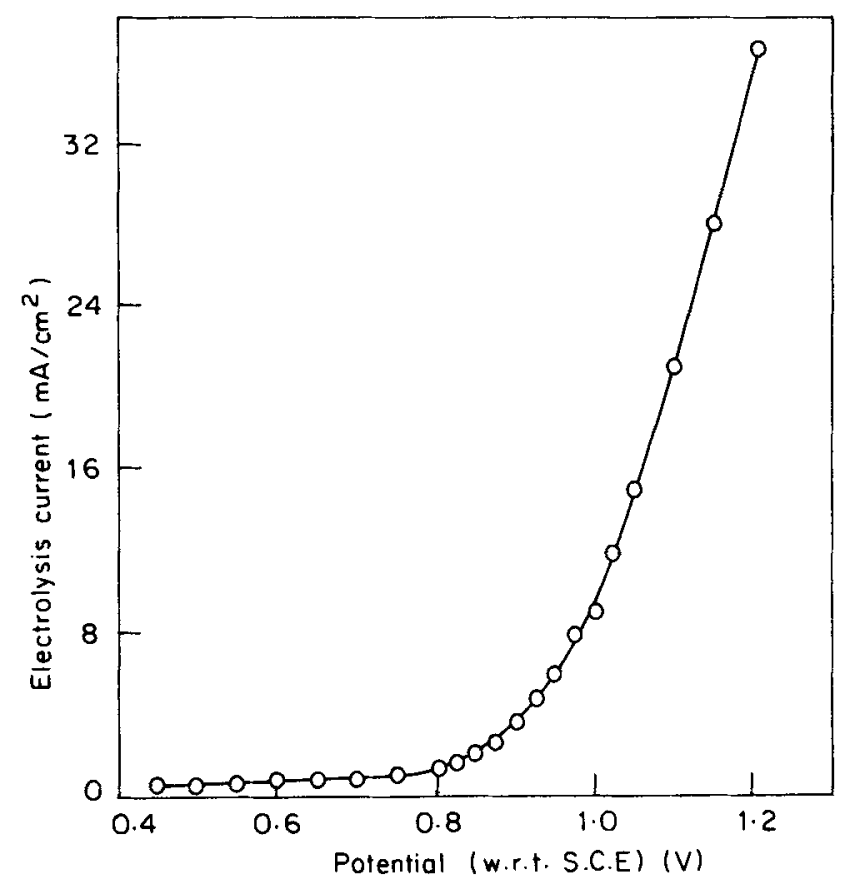

Figure 5. Polarization curve for AlSb electrodeposition. 


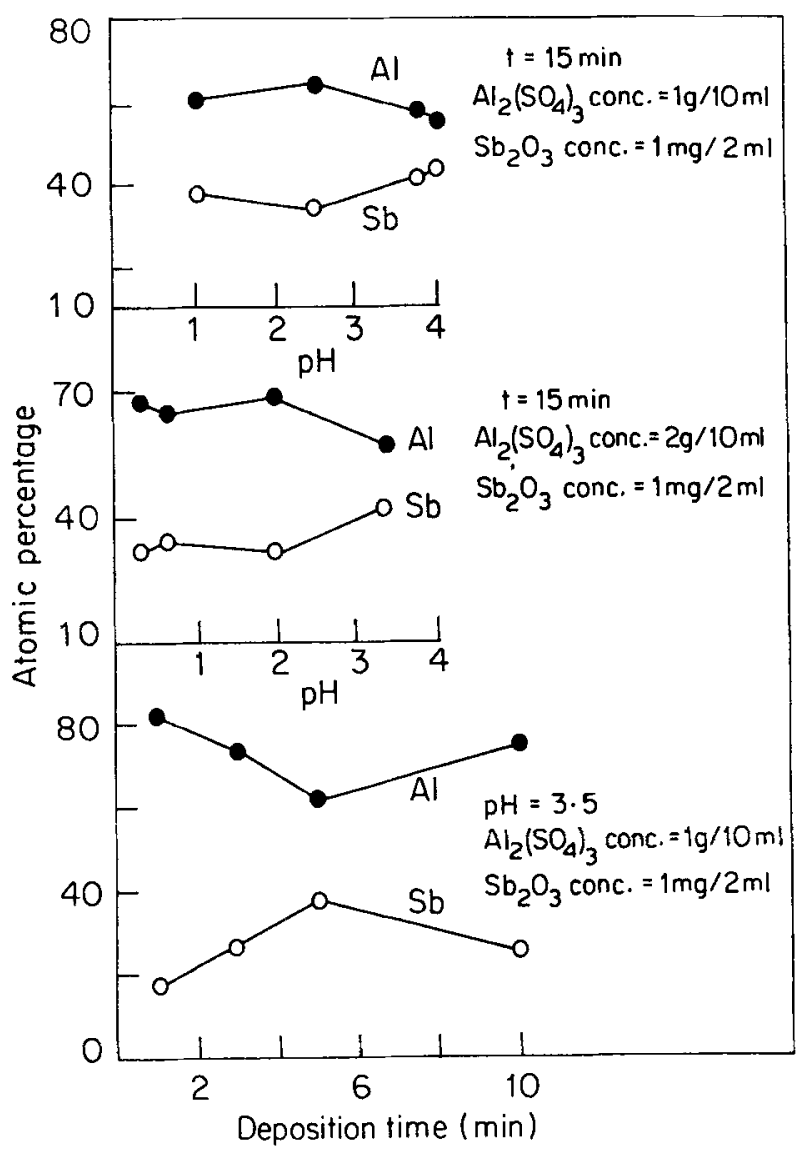

Figure 6. Relative composition of $\mathrm{Al}$ and $\mathrm{Sb}$ in the electrodeposited $\mathrm{AlSb}$ films at (a) and (b) different $\mathrm{pH}$ and (c) different deposition times.

$V_{\mathrm{oC}}$ and $J_{\mathrm{sc}}$ of the PESC depend on the stoichiometry of GaAs-film. A marked decrease of photoresponse was observed for the variation of film stoichiometry in either direction. However, the PESC of GaAs/ $\mathrm{S}_{2}^{2-}, \mathrm{S}^{2-}$ is not stable, as $V_{\text {oc }}$ and $J_{\text {sc }}$ deteriorates with time which indicates the chemical corrosion of the film.

The non-aqueous redox-couples like $\mathrm{GaAs} / \mathrm{MV}^{2+1+}$ and $\mathrm{GaAs} /$ ferrocene. ferrocenium in $\mathrm{CH}_{3} \mathrm{CN}$ as non-aqueous electrolyte make the PESC stable. However, no significant change in the photoresponse of the film is seen. Table 3 summarizes the solar cell characteristics of GaAs film in different redox-electrolytes.

Similar studies were carried out for AlSb films. However, AlSb films hydrolysed quickly in aqueous medium as follows (Rudorff and Kohlmeyer 1954):

$$
\begin{aligned}
& \mathrm{AlSb}+2 \mathrm{H}_{2} \mathrm{O} \stackrel{\text { fast }}{\longrightarrow} \mathrm{AlSbO}+\mathrm{H}_{2} \mathrm{O}+\mathrm{H}_{2}, \\
& \text { AlSbO. } \mathrm{H}_{2} \mathrm{O}+\mathrm{H}_{2} \mathrm{O} \stackrel{\text { slow }}{\longrightarrow} \mathrm{Al}(\mathrm{OH})_{3}+\frac{1}{2} \mathrm{H}_{2} .
\end{aligned}
$$

Hence, the use of non-aqueous redox-couples becomes an essential requirement for the fabrication of AlSb-based PESC. 
Table 3. Solar cell characteristics of GaAs and AISb films in different redox electrolytes.

\begin{tabular}{|c|c|c|c|c|c|}
\hline $\begin{array}{l}\text { Electro- } \\
\text { deposited } \\
\text { photoelectrode }\end{array}$ & $\begin{array}{l}\text { Electrolyte/ } \\
\text { couple }\end{array}$ & $\begin{array}{c}\text { Illum. } \\
\text { intensity } \\
\left(\mathrm{mW} / \mathrm{cm}^{2}\right)\end{array}$ & $\begin{array}{c}V_{\mathrm{oc}} \\
(\mathrm{mV})\end{array}$ & $\begin{array}{c}J_{\text {sc }} \\
\left(\mathrm{ma} / \mathrm{cm}^{2}\right)\end{array}$ & Stability \\
\hline $\mathrm{Ga}_{1.04} \mathrm{As}_{0.96}$ & Aqueous $/ \mathrm{S}_{2}^{2-}, \mathrm{S}^{2-}$ & 60 & 195 & $2 \cdot 2$ & Unstable \\
\hline $\mathrm{Ga}_{1.04} \mathrm{As}_{0.96}$ & $\mathrm{CH}_{3} \mathrm{CN} / \mathrm{MV}^{2+1+}$ & 100 & 200 & $2 \cdot 0$ & Stable(slow response) \\
\hline $\mathbf{G a}_{1.04} \mathbf{A s}_{0.96}$ & $\begin{array}{l}\mathrm{CH}_{3} \mathrm{CN} / \text { ferrocene, } \\
\text { ferrocenium }\end{array}$ & 80 & 150 & $0 \cdot 3$ & $\begin{array}{l}\text { Stable(slow } \\
\text { response) }\end{array}$ \\
\hline $\mathrm{Al}_{1 \cdot 12} \mathrm{Sb}_{0.88}$ & $\mathrm{CH}_{3} \mathrm{CN} / 2 I^{-}, I_{2}$ & 100 & 210 & $0 \cdot 35$ & Stable(slow response) \\
\hline$A l_{1 \cdot 12} S b_{0.88}$ & $\mathrm{CH}_{3} \mathrm{CN} /\left[\mathrm{Ph}\left(\mathrm{NO}_{2}\right)\right]^{0 /-}$ & 100 & 240 & $0 \cdot 1$ & Stable (slow response) \\
\hline
\end{tabular}

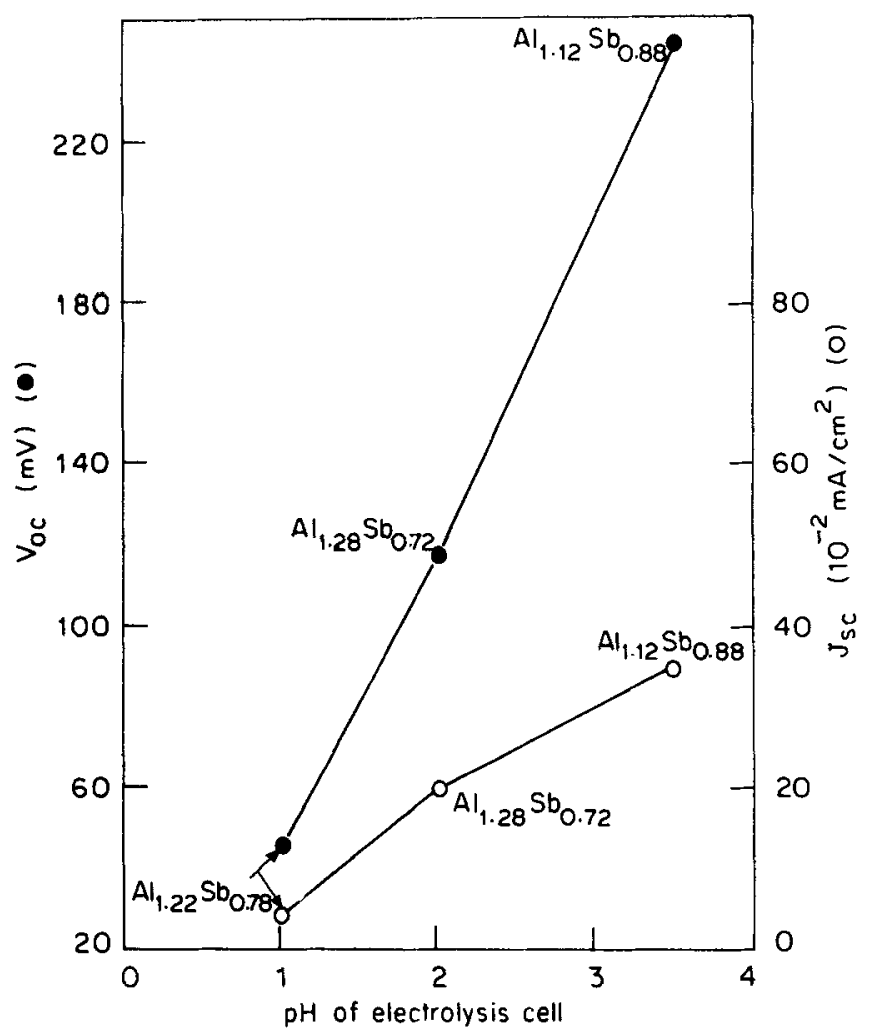

Figure 7. Photovoltage and photocurrent of the electrodeposited PESC system using semiconducting $\mathrm{Al}_{x} \mathrm{Sb}_{y}$ films electrodeposited at various $\mathrm{pH}$ values (for other conditions see the text).

Figure 7 shows the $V_{\text {oc }}$ and $J_{\text {sc }}$ of different PESC which used AlSb films prepared under different $\mathrm{pH}$ conditions. The corresponding stoichiometries are also given in the figure. As pointed out earlier, the best film had the stoichiometry $\mathrm{Al}_{1 \cdot 12} \mathrm{Sb}_{0.88}$. The characteristics of PESC using this film as photoelectrode are listed in table 3 for two different redox-couples.

The detailed $J-V$ characteristics of PESC showed that the GaAs film PESC had an efficiency of $\sim 1 \%$ with a fill factor $\sim 0.5$. It is hoped that if the films are prepared to bring better stoichiometry and uniformity, the GaAs film PESC can be a competitive 
and economically viable system. However, AlSb system is not recommended for terrestrial use as it is likely to hydrolyse if perfect sealing is not attained.

\section{Acknowledgement}

Thanks are due to DNES (Govt. of India) for financial assistance.

\section{References}

Azaiez C, Levy F, Campet G and Claverie J 1986 in Report on: The sixth International conference on photochemical conversion and storage of solar energy, July 21-25, Paris (ed.) G V Subba Rao

Chandra S 1985 Photoelectrochemical solar cells (New York: Gordon \& Breach)

Chandra S and Khare N 1987 Semicon. Sci. Technol. 2 214, 220

Chandra S and Pandey R K 1982 Phys. Status Solidi A72 415

Gabouze N and Gorochov O 1986 in the Report on: The sixth International conference on photochemical conversion and storage of solar energy, July 21-25, Paris (ed.) G V Subba Rao

Gerischer H 1979 in Solar energy conversion and storage (ed.) B O Seraphin (Berlin: Springer Verlag) 31 115

Heller A 1977 in Semiconductor liquid junction solar cells (Princeton: Electrochem. Soc.) 77-3

Heller A, Miller B and Trieb F 1981 Appl. Phys. Lett. 38282

Parkinson B A, Heller A and Miller B 1979 J. Electrochem. Soc. 126954

Rudorff W and Kohlmeyer E J 1954 Z. Metall. 45608

Switzer $1986 J$ J. Electrochem. Soc. 138722

Tuffs B J, Abraham I L, Santangelo P G, Ruba G N, Casagrande and Lewis N S 1987 Nature (London) 326861 